\title{
The vision of bedfast nursing home residents of their quality of life and the contribution of technological innovations in and around the bed
}

Citation for published version (APA):

Martens, I., Verbeek, H., Aarts, J., Bosems, W. P. H., Felix, E., \& van Hoof, J. (2018). The vision of bedfast nursing home residents of their quality of life and the contribution of technological innovations in and around the bed. Journal of Enabling Technologies, 12(2), 35-44. https://doi.org/10.1108/JET-01-20180003

Document status and date:

Published: 01/01/2018

DOI:

10.1108/JET-01-2018-0003

Document Version:

Publisher's PDF, also known as Version of record

Document license:

Taverne

Please check the document version of this publication:

- A submitted manuscript is the version of the article upon submission and before peer-review. There can be important differences between the submitted version and the official published version of record.

People interested in the research are advised to contact the author for the final version of the publication, or visit the DOI to the publisher's website.

- The final author version and the galley proof are versions of the publication after peer review.

- The final published version features the final layout of the paper including the volume, issue and page numbers.

Link to publication

\footnotetext{
General rights rights.

- You may freely distribute the URL identifying the publication in the public portal. please follow below link for the End User Agreement:

www.umlib.nl/taverne-license

Take down policy

If you believe that this document breaches copyright please contact us at:

repository@maastrichtuniversity.nl

providing details and we will investigate your claim.
}

Copyright and moral rights for the publications made accessible in the public portal are retained by the authors and/or other copyright owners and it is a condition of accessing publications that users recognise and abide by the legal requirements associated with these

- Users may download and print one copy of any publication from the public portal for the purpose of private study or research.

- You may not further distribute the material or use it for any profit-making activity or commercial gain

If the publication is distributed under the terms of Article $25 \mathrm{fa}$ of the Dutch Copyright Act, indicated by the "Taverne" license above, 


\title{
The vision of bedfast nursing home residents of their quality of life and the contribution of technological innovations in and around the bed
}

\author{
I. Martens, H. Verbeek, J. Aarts, W.P.H. Bosems, E. Felix and J. van Hoof
}

\begin{abstract}
Purpose - Over 8 per cent of the Dutch nursing home population is bedfast, and this number is slowly increasing. The quality of life $(\mathrm{QoL})$ of this population is lower than that of residents who are still mobile. Little research has been conducted on how to improve the QoL of this bedfast population, particularly through making technological adjustments to the bed and the direct surroundings. The purpose of this paper is to gain insight into the QoL of bedfast residents and how to improve this through technology.

Design/methodology/approach - A mixed-method multi-case study with thematic analysis was conducted in two nursing homes with seven participants based on semi-structured interviews and Short Form-12 questionnaire.

Findings - The major causes of the experienced low QoL were the limited opportunities for engaging in social contacts with others, and coping with the dependency on other people and having limited control. Participants suggested improvements of QoL through the application of modern communication technologies to engage in social contacts and to control the bed itself and environment around the bed.

Practical implications - The results may help improve the design of the bed and the direct environment in order to improve the QoL of bedfast nursing home residents.

Originality/value - The QoL of bedfast nursing home residents has not been studied before in relation to the bed itself and technological solutions that may help improve the QoL and level of control.

Keywords Dependency, Control, Immobility, Technology, Bed-bound, Bed-ridden, Nursing home, Bed, Mattress, Quality of life

Paper type Research paper

\section{Introduction}

The number of bedfast residents in Dutch nursing homes is increasing. In the year 1995 about 4.6 per cent of the residents were bedfast; in 2011 this number had risen to 5.7 per cent. If these numbers are extrapolated (CBS-Statistics Netherlands, 2007), over 8 per cent of the population is currently expected to be bedfast. This trend matches the recent developments in which only those people with the most complex needs are eligible for nursing home admission. There are many definitions of the term "bedfast", and - to our knowledge - there is no instrument to determine "bedfastness" or classify the degree of the situation (Zegelin, 2008). Also, the words bed-ridden and bed-bound appear in the somewhat older literature. Someone who is bedfast is limited to his or her bed due to illness or physical impairments (de Klerk, 2005). A person is bedfast if he or she spends the larger part of the day (and night) in bed (Zegelin, 2008). According to Fielding et al. (2011), a bedfast person is not able to get out of bed independently, which leads to the person spending the majority of the day in bed. Based on these three definitions, we assume that someone is bedfast if he or she spends at least $12 \mathrm{~h}$ per day in bed, and is unable to get out of bed independently due to illness or a physical impairment.
\end{abstract}

(Information about the authors can be found at the end of this article.)

Received 10 January 2018

Revised 13 March 2018

Accepted 15 March 2018

(C) I. Martens, H. Verbeek, J. Aarts, W.P.H. Bosems, E. Felix and

J. van Hoof. Published by Emerald

Publishing Limited. This article is

published under the Creative

Commons Attribution (CC BY 4.0)

licence. Anyone may reproduce,

distribute, translate and create

derivative works of this article

(for both commercial \&

non-commercial purposes), subject

to full attribution to the original

publication and authors. The full

terms of this licence may be seen

at http://creativecommons.org/

licences/by/4.0/legalcode

This research was funded as part of the SIA RAAK MKB project 2015-02-24 M, SCHAT-Smart Care Homes and Assistive

Technologies. Vivette van Cooten and Birgit Kersten are thanked for their support. 
Research focusing on bedfast nursing home residents is scarce. In general, studies suggest that from a residents' perspective, being bedfast has a negative impact on the quality of life (QoL). Older people who are bedfast due to physical impairments require assistance with basic activities of daily living, and are at risk of decubitus and developing blood clots (Campbell, 2009). Rubin et al. (2016) studied how 180 hospitalised patients over 60 years of age with serious illnesses evaluated states of cognitive or functional impairment relative to death. Not being able to get of bed was considered worse than death by half of the participants, and slightly less bad than incontinence and having to rely on a breathing tube in order to stay alive. Living in a nursing home was, in itself, considered to be worse than death by about 30 per cent of the respondents. One study from Turkey showed that the QoL of bedfast people is much lower than that of people who are still mobile (Arslantas et al., 2009). Apart from the physical and mental challenges faced by bedfast persons, there are risks associated with lower evacuation times in case of fires (Strating et al., 2015). Furthermore, nursing staff find it challenging to care for residents remaining in bed (lecovich and Rabin, 2014).

In order to prevent people from becoming bedfast, it is important that residents get stimulated to move as often as possible. However, residents in nursing homes often remain inactive during most of the day, being in a lying or sitting position (den Ouden et al., 2015). Moreover, participation in daily activities itself already helps maintain physical functioning (Bates-Jensen et al., 2004), and is associated with a higher QoL (Edvardsson et al., 2013). Nursing staff have a major role in increasing activity levels of nursing home residents, although practice shows that this is challenging. den Ouden et al. (2017) recently showed that in almost half of the (I)ADL tasks, nursing staff took over activities of residents, for a large part unnecessarily.

In recent times, there has been an increasing focus on the implementation of technology in the nursing home environment in order to support the provision of care by professionals, and improve the QoL, independence and degree of control of residents. Little to no research has been conducted on how technological solutions may help improve the QoL of older people who are bedfast. The domain of research with bedfast participants seems an understudied area, and the research focus is on the prevention and management of pressure sores (Okuwa et al., 2006), for which special treatment protocols and mattresses are used.

The aim of this study is twofold, namely:

1. to gain insight into the experiences of being bedfast and the impact this has on residents' perceived QoL; and

2. to investigate how the QoL of bedfast nursing home residents can be improved, with a special focus on the impact of the bed and technology.

\section{Methodology}

A mixed-method study was conducted, comprising of in-depth semi-structured interviews, following a multi-case study approach (Swanborn, 2013).

\subsection{Setting and participants}

The study was conducted in the wards for residents with physical impairments of two nursing homes in The Netherlands. The principal investigator (IM) engaged in a round of participatory observations prior to the recruitment in one of the nursing homes, where only three bedfast residents lived. This led to the inclusion of a second nursing home, where nine bedfast residents lived. Members of staff assisted in recruiting potential participants, and their initial family carers were also informed about the study through an information letter. The need for ethical approval was waived (Fontys Committee for Ethics in Research) due to the character of the study. A total of 7 participants out of 12 potential participants agreed to take part in the study and signed informed consent (residents, in conjunction with their initial family carers) (Table I). Participants had to be able to speak and communicate in Dutch. Due to late-stage dementia and inability to speak, two residents in the first nursing home and three residents in the second were excluded 
Table I List of participants and their characteristics

\begin{tabular}{|c|c|c|c|c|c|c|c|c|c|}
\hline Participant & $\begin{array}{l}\text { Age } \\
\text { (y) }\end{array}$ & $\begin{array}{l}\text { Sex } \\
(M / F)\end{array}$ & $\begin{array}{l}\text { Self-reported } \\
\text { psychological } \\
\text { well-being }\end{array}$ & $\begin{array}{l}\text { Self-reported physical } \\
\text { well-being }\end{array}$ & $\begin{array}{c}\text { Number of hours spent in } \\
\text { bed per day }\end{array}$ & $\begin{array}{l}\text { Nursing } \\
\text { home }\end{array}$ & $\begin{array}{l}\text { Duration of } \\
\text { residence (mo) }\end{array}$ & $\begin{array}{l}\text { PCS } \\
\text { SF-12 }\end{array}$ & $\begin{array}{l}\text { MCS } \\
\text { SF-12 }\end{array}$ \\
\hline A & 94 & F & Depression & $\begin{array}{l}\text { Disturbed equilibrium. } \\
\text { Arthritis in knees }\end{array}$ & 20 & 1 & 35 & 24.0 & 19.1 \\
\hline B & 83 & F & - & Amputation of a leg & 14 & 2 & 6 & 23.8 & 36.1 \\
\hline C & 97 & F & $\begin{array}{l}\text { Feelings of } \\
\text { loneliness }\end{array}$ & $\begin{array}{l}\text { Arthritis in knee, shoulder } \\
\text { and hand }\end{array}$ & 12 & 2 & 12 & 33.4 & 47.4 \\
\hline D & 61 & M & - & Amputation of the legs & 15 & 2 & 1 & 17.3 & 50.4 \\
\hline E & 84 & M & - & Left-sided paralysis & 14 & 2 & 30 & 26.5 & 26.9 \\
\hline $\mathrm{F}$ & 78 & $\mathrm{~F}$ & Depression & Back pains & 13 & 2 & 60 & 29.1 & 18.9 \\
\hline G & 75 & M & - & Left-sided paralysis & 15 & 2 & 6 & 19.3 & 54.2 \\
\hline
\end{tabular}

from the study. The participants in this study are either fully bedfast, or seated in a special chair, and fully dependent on a care professional (Table I). The people who were included were classified based on the number of hours they spent in bed and not on the amount of time they spent additionally being seated in a wheelchair or special chair.

The Short Form (SF-12) questionnaire was used in this study. Of the 12 questions, 6 are related to the functional status, such as physical and social functioning, and 4 questions are related to a person's well-being. The results of the SF-12 are expressed as physical and mental condition of well-being scores (PCS and MCS) (Table I). All seven participants had a very low QoL, and six of them had very low scores on physical well-being. In the domain of mental well-being, three participants had average scores, and three participants had very low scores.

\subsection{Interviews and questionnaire}

A semi-structured interview was held in the private room of the residents, which lasted for about $45 \mathrm{~min}$. The interviews were held based on a topic list, which was tested with a resident who spent about ten hours per day in bed and who was unable to get out of bed independently. Interviews started by asking general questions, including the number of hours spent in bed, as far as these items were not covered by the SF-12 questionnaire. The two domains were the QoL and the bed and its surroundings. Topics of the first domain included questions about the social, psychological and physical aspects of daily living, such as the frequency and quality of relationships, mood and mental status and physical and sensory impairments. The second domain concerned questions about the bed itself and the mattress (considered as technological solutions given the complex design of these products); the features of the bed; and the position of the bed, the room itself, technologies in the room including home automation, communication devices, alerts and emergency response systems, controls. Supplementary and probe questions were asked, particularly in relation to the bed and the technologies that were already used, or features and technologies that were missed or deemed essential by the participants.

\subsection{Data analysis}

First, cases were individually described. The presentation of the cases follows the same structure: general data, mental well-being, social functioning, dependency/control and the bed. The interviews were transcribed verbatim, and these transcripts were sent back for member check. During the data analysis, data saturation was reached. Therefore, a six-step thematic analysis (Braun and Clarke, 2006) was conducted by two of the authors. Consensus was reached about the results. In order to provide a more in-depth overview of the cases, the cases are presented as short life stories, which are followed by a thematic analysis of factors related to the use of technology in and around the bed. 


\section{Results}

First, the cases are described in detail. Second, results of the thematic analyses are presented.

\subsection{Case studies}

3.1.1 Case respondent A. Respondent A is bedfast mainly because of dizziness, especially when she tries to sit upright. Overall, she does not feel well. The main problem is facing boredom, as she had no hobbies or activities that she can participate in. She feels locked out of the outside world, as she can no longer watch the news or read a paper. She joins other residents for meals, but she is not able to engage and interact with them. This is why she returns to bed around 18:00, so that she can fall asleep and forget about her days. Social interaction with next of kin is limited to a fortnightly visit by a daughter, and there are weekly visits by a friend. She dreads being dependent and wishes to do as many things as possible. She would like to have a remote control to operate the lights and curtains. Her bed is fixed in height and cannot be lowered or raised. Because she thinks the bed itself is too low, she has an extra mattress. She does not need a bed that can be positioned electronically. She compares a nursing home bed to a hospital bed. Because of the dizziness, she does not want her bed to have a head-end that can be raised. Being able to raise the mattress at the leg-end is not considered necessary, as she uses a little pillow to lift one of her knees.

3.1.2 Case respondent $B$. Respondent $B$ has a low expectation of the day to come when she wakes up, as her life is boring. She has no activities that she enjoys, she has little interest in things around her and takes no initiative. One daughter visits on a daily basis. The social interactions with other residents are very limited, but sufficient. At the same time, she indicates that she does not like sitting alone in her room all day long. Sometimes she goes to a communal room to engage with others. She wished she was able to conduct tasks independently like getting out of bed without the use of a hoist, which frightens her. From the bed, she is able to control the front door. She would like to control the lighting from her bed or wheelchair, too. Instead she can alert the staff with a push button. The bed itself is fine and lying in bed is not a burden. She is able to lie well during the whole night on a normal mattress. The positioning of the bed in the room and the position the bed is in are satisfactory. She used the positioning functionality to adjust the back-end of the mattress. She cannot adjust the leg-end of the mattress, but this is not a must. The bed rails give her a sense of security when going to sleep. She gets help from staff to adjust these rails.

3.1.3 Case respondent $C$. Respondent $C$ spends her days in bed mainly because of arthritis. She is not able to walk around independently. Spending her days in bed is not a voluntary choice, but the care professionals make her go to bed at 19:30 after spending time in the living room. She is taken out of bed at 07:30. When in bed, she tends to watch television until midnight. She looks forward to group activities, because it is an opportunity to meet and engage with others. Having no children, she is only visited by a niece and a nephew on a weekly basis, as well as by a neighbour. She lives in a room in the middle of a corridor, so that she can enjoy people walking by if she leaves her door open. She is taken out of bed using a hoist, which illustrates her dependence on others. She likes the fact that she can operate the front door. She also wishes to control curtains and lighting using a remote control, as staff forgot to shut the curtains once. The bed is satisfactory, including the standard mattress. She states that she would have liked to keep her own sheets, as these were brand new when she was admitted to the nursing home. She likes the fact she has different sheets and blankets for each of the seasons. She is fine with the rails of the bed being in the upright position and the positioning of the bed in the room, which allows her to look through the window. She has problems operating the buttons of the remote control. One time, this made her leg-end go up all the way, and she did not know how to make it go down again.

3.1.4 Case respondent $D$. Respondent $D$ experiences pain all day long and at 19:00 he is administered additional oxygen to cope with the consequences of COPD. He does not mind to be in bed early, even though he is taken out of bed as late as 10:00 in the morning. Respondent $D$ likes to go outside, smoke a cigarette, read a paper and go to the supermarket to do groceries. He has no children, but is visited by nieces. He eats inside his room, as he had some negative 
experiences in the communal dining room. He is still a very sociable person who talks a lot to other residents. He does not feel dependent, as he feels he is able to do a lot of things independently. The two things he needs help with is getting in and out of bed and visiting the toilet. Having experienced pressure sores in the past, he sleeps on an inflatable air-mattress. If he ever needs to go to hospital, he only wants to go if he can have an air-mattress too. He is satisfied with the self-adjustment settings of the bed.

3.1.5 Case respondent $E$. Respondent $E$ deals with the consequences of a stroke which led to a half-sided paralysis. He is put in bed at 19:30 every evening and taken out again around 08:00 in the morning. In the afternoon he also spends about one hour in bed. He actually does not want to be in bed any longer, because he feels that his condition is deteriorating rapidly. Feeling dissatisfied with his life, he sometimes gets angry. He has a hard time dealing with being alone, and reading and watching television are daily pastimes. He enjoys being outdoors, and once in a while he drives around in a mobility scooter. He gets daily visits from one of his children. The social interaction with fellow residents is limited, which he regrets. He enjoys participating in the various activities offered by the nursing home, such as eating together. At present, he operates the light switches with a shoehorn to press the switches. He is not satisfied with the temperature control and the draughty air-based heating and cooling system. Neither is he satisfied with the bed and the mattress, as it makes him perspire a lot. He actually looks forward to getting a new foam mattress. At night, he tells the nurses when he is in a comfortable position. He is rolled, so he lies on his side and he is kept in the desired position by placing two pillows behind his back. The blanket has many frayed ends, which tickle his face. There are times when he feels locked up inside his bed, and he tries to climb out at night, despite the rails being in the upright position. The control buttons of the bed are not very clear, which makes him end up in the strangest of positions.

3.1.6 Case respondent $F$. Respondent $F$ has back pains, and spends a lot of time in a wheelchair. She is tired of living, and misses the ability to be cheerful. When she goes to bed at 19:30, she is devoid of energy and happy to go to bed. However, she cannot fall asleep, as she is worrying all of the time. One of her sons visits her twice a week. She wishes she had more conversations with others. She says that she is not the ideal person to talk to, because of her wish to die. Because she does not want to spend all day alone in the own room, she decided to spend time in the lounge. When in need for something, she is able to alert using a bell. She has no need for remote controls, as she is already able to operate the automated front door. She can hear the sounds coming from the door, but she has no idea whether the door is actually open or closed. The bed itself is fine as it is, as is the inflatable air-mattress. The staff adjust the bed in the position she wants. She has no need to do the adjustments herself.

3.1.7 Case respondent $G$. Respondent $G$ deals with the consequences of a half-sided paralysis, delirium and an impaired vision. He is put to bed at 18:45 and taken out again at 07:30 in the morning. In the afternoon, he returns to bed for another two hours. He has problems remaining seated in a wheelchair for prolonged times, which is then tilted in order to shift the pressures on his body. His wife visits every day, and his three children visit on a regular basis. He does not interact often with fellow residents, but he would like to take part in activities. He is reluctant to ask for help by pressing an alert. He is not satisfied with the bed; the bed frame is too large for the small mattress, which makes the pillows fall behind the mattress all the time. The inflatable airmattress is satisfactory and comfortable. He does not mind if the bed rails are in the upright position, it keeps him secure from climbing out at night. He can adjust the bed himself, but he has trouble understanding how to operate the control buttons. Whenever the care professionals adjust his bed, he asks them about how they did it, and he tries to copy. He thinks that the wire connecting the control device to the bed itself is inconvenient, as it makes the device much heavier. He has suggested instructions be provided for new residents about how to operate the bed. He would like a built-in light in the bed frame, which would allow him to use a dim light without having to switch on the general lighting at night.

\subsection{Thematic analysis}

Two main themes have come to the fore from the interviews, which are related to technology, namely acceptance of dependency in relation to technology, and innovations to the bed. 
3.2.1 Acceptance of dependency in relation to technology. Six out of seven participants are taken out of and put in bed using a hoist, which is seen as a confirmation of being dependent on a care professional for a basic task. Accepting this dependency can be difficult:

[Respondent F]: I can't do anything by myself anymore. It makes me feel so bad, and it is so hard to cope with. I got depressed when I became totally dependent on others. When they take me out of bed with the hoist, the nurses chat with one another, and not with me. Why don't they talk to me too? I feel left out!

Four out of seven participants are not only in bed during the night, but also during the afternoon. The other three spend at least $12 \mathrm{~h}$ in bed during the night time hours, something that is not of their own choice. All participants spend a part of the day being seated in a wheelchair, although respondent $A$ is able to walk short distances with the use of wheeled walker. Despite these abilities, there seems little time to supervise her during her short walks. And it is also noteworthy that this participant spends the longest time of day in bed, about $20 \mathrm{~h}$ :

[Respondent A]: My health is getting worse so fast. I have a wheeled walked, but they won't let me walk on my own. Only when someone guides me. But they never have the time to walk with me. It would mean the world for me if people practice more with me, so I become independent again. It would mean the world for me if I could only walk once a day.

Six of the participants explicitly stated that they feel dependent on others and that they have problems accepting this feeling. This is also expressed in the overall reluctance to ask for help, for instance, by pushing the alert buttons. Four of the participants stated that they only ask for help if it is truly necessary. When the residents have to visit the toilet, they often alert when it is too late and have already used incontinence material. Three participants explicitly mentioned that they often have to wait for help to arrive for too long:

[Respondent C]: If I push the alert button, I often have to wait for half an hour, before a nurse stops by. The longest I had to wait for was 45 minutes. As I had to hold up my urine for too long, I got a urinary tract infection, and now I have to live with a catheter. I also had to hold up my [faeces]. It gives me bad stomach aches.

In order to regain a sense of control, technological options were mentioned. Five participants expressed their wish to be able to control the lighting from the bed with a remote control. Four participants wanted to operate the curtains from the bed using a remote. And three participants wanted to control automated and operable windows from the bed:

[Respondent E]: I don't want to wait for half an hour. I would be so happy if I could control the lights, the curtains and the window by remote control. I would make me feel less dependent. And it is more convenient than using a shoe horn for switching off the lights.

The remote itself does not appear to have been well designed for disabled people. Large buttons, a more logical layout and an ergonomic design including a flat back in order to prevent it falling off a surface when it is put down would be helpful:

[Respondent G]: I'd like to have a single remote control for everything; the television, the lights, the window, and the curtains. The remote control needs to be flat on the back side, so that it stays on the bedside table without falling off.

Respondents wanted a quick follow-up when in need for assistance. One option that was mentioned was a so-called toilet-button, which could be used to indicate one has to make a sanitary stop, and which expresses the urgent need for a member of staff:

[Respondent D] I had to leave my own home for a nursing home, as the home care organisation could not guarantee that they would be at my bed when I had to go to the toilet. I wish I had a button to push.

These controls could be part of a tablet computer, which could also be used for social interaction with loved-ones, for instance, through sharing photos and Skype conversations from the bed:

[Respondent E]: She < his sister > lives in America. l'd like to Skype with her on the computer in my room, but I can't [operate the device].

3.2.2 Innovations to the bed. The bed, in which a significant amount of time is spent by the participants, is an integral part of daily life. Therefore, it is important that the bed is comfortable, 
and can be adjusted to personal preferences. Two of the participants were not satisfied with the bed. One of them stated that the mattress was the source of discomfort. In the other case the size of the bed was too large compared to the size of the mattress, which made the pillows drop in between the bed frame. Four of the participants had a normal mattress and three of them were satisfied with it. The other three had an inflatable air-mattress. The satisfaction with air-mattresses was large:

[Respondent D]: If I ever need to go to hospital, I won't go lie in a bed if there is no air-mattress.

One of the participants explicitly mentioned the role of the mattress in excess perspiration, which wakes him up at night and impairs his sleep quality. The position of bed was satisfactory for six of the participants, particularly, because if they wished change its position, they had already done so. One participant wished to move his bed in order to have some space for his wheelchair next to the window:

[Respondent E]: The bed should be moved to another place in the room. l'd love to sit in front of the window with the wheelchair.

All seven participants were satisfied with the settings (positioning) of the bed, although in one case the bed could not be adjusted. Five of them managed to adjust their beds themselves, using the control buttons, though three participants found it hard to do so:

[Respondent C]: The buttons all look the same.

One participant mentioned the connection cable to be obstructive and contributed to the weight of the device. In the case of the one bed that could not be adjusted, there was no need for an adjustable bed as such beds that resembled a hospital bed. The look and feel of the bed itself was thus an issue for this participant, who stated that a bed needed to look like a regular bed she had at home. She was also afraid to slide down the mattress if she adjusted the bed in such a position that the head-end was raised up, being in half-seated and half-reclined position. One of the participants valued the help from the nursing staff in adjusting the bed frame. Six participants had bed rails, which helped them to stay in bed and feel secure. Only one of the residents expressed the wish for a built-in night light:

[Respondent G]: I don't understand these buttons, and the remote control. When the nurse stops by to adjust my bed, I ask her which buttons she used, so I can copy cat her the next time.

\section{Discussion}

\subsection{Strengths and limitations}

One of the great strengths of this study is that it explores the actual perspectives of bedfast nursing home residents. Moreover, it makes a contribution to the limited evidence currently available on the QoL of these people and their use of and attitudes towards technology (for instance, Imai et al., 2015). This study has shown that residents who are bedfast in nursing homes have a relatively low QoL, which was related to being confined to bed for prolonged times, experiencing a large degree of dependency on others, limited participation in social and daily life and displayed different ways of adjusting or coping with their situation. Participants in this study indicated that small, but significant, improvements to their perceived QoL could be achieved by the introduction of new technologies to control the bed, to ask for help from nursing staff, to control the room itself (curtains, opening doors) and to engage in social contacts, for instance, through the use of tablet computers. The interviews showed that the limited opportunities for social engagement and social participation, and different styles of coping with being dependent on others are important factors in this low level of experienced QoL.

This study also has some limitations. Despite the predicted percentage of bedfast nursing residents, it was difficult to recruit participants. Many of them have severe psychogeriatric health problems, which meant that they could not be included in the study. The participants of the study are not fully bedfast, and qualify in the lower end of the spectrum of bedfastness. Future research could include participants occupying their beds for a wider range of hours. 


\subsection{Relation to other studies}

There are similarities between the findings of this study and an earlier one by van Hoof et al. (2015), in which professionals explored and generated design concepts for the direct environment of bedfast residents through interdisciplinary participatory design sessions. The stimulation of social relationships was an important theme in eight of the scenarios. The professionals suggested the use of tablet computers in order to stimulate social interaction with relatives, friends and co-residents (van Hoof et al., 2015). Additional features of such tablet computers would be functionalities like the control of lighting and curtains. Participants in this study indicated that such features may help them in improving their sense of control. One issue that emerged from the interviews was the need to go use the toilet. Imai et al. (2015) studied the optimal bed reclining angle for promoting efficient and safe defecation in bedfast patients. They found that higher reclining angles may enable safer and more efficient defecation. In our study, people explicitly indicated that they wanted to physically use the toilet, instead of being assisted defecating in bed.

\subsection{Future research}

Future research could test the proposed solutions from this study with bedfast residents. The question remains if people, who are bedfast, are actually able to control devices such as tablet computers, as we know little to nothing about the digital capabilities of these people. This would require more in-depth usability and human factors studies, for instance, in terms of dexterity or visual acuity. It is not certain if these suggested improvements do indeed lead to a higher level of perceived independence, control, autonomy and QoL. At least we could accept that not all are able to use these devices but if they can, it might improve their well-being through an enhanced ability to control the immediate environment. Future studies could also differentiate between the various levels of being bedfast and personal coping styles, as these factors may impact the relevance of proposed technological improvements.

\section{Conclusions}

Bedfast nursing home residents included in this study experienced a low QoL, which partly stems from the dependence on care professionals. Participants found it hard to accept that they are no longer independent, which is also a cause for postponing a call for help for as long as possible. They stated that being able to control features in the room from the bed would improve their independence and autonomy. Overall, participants missed having social interaction with others. The beds themselves were considered comfortable, especially by the participants who had inflatable air-mattresses. Tablet computers or remote controls could be used to adjust beds to personal preferences. Such interfaces should be easy to understand and help people to adjust the bed without finding themselves in unwanted positions that are hard to correct and require assistance from care staff.

\section{References}

Arslantas, D., Ünsal, A., Metintas, S., Koc, F. and Arslantas, A. (2009), "Life quality and daily life activities of elderly people in rural areas, Eskişehir (Turkey)", Archives of Gerontology and Geriatrics, Vol. 48 No. 2, pp. 127-31.

Bates-Jensen, B.M., Schnelle, J.F., Alessi, C.A., Al-Samarrai, N.R. and Levy-Storms, L. (2004), "The effects of staffing on in-bed times of nursing home residents", Journal of the American Geriatrics Society, Vol. 52 No. 6, pp. 931-8.

Braun, V. and Clarke, V. (2006), "Using thematic analysis in psychology”, Qualitative Research in Psychology, Vol. 3 No. 2, pp. 77-101.

Campbell, K.E. (2009), "A new model to identify shared risk factors for pressure ulcers and frailty in older adults", Rehabilitation Nursing, Vol. 34 No. 6, pp. 242-7.

CBS-Statistics Netherlands (2007), "Verzorgingshuizen: capaciteit, bewoners, personeel, exploitatie, 1995-2005 (Residential care facilities: capacity, residents, staff, exploitation, 1995-2005)", Statistics Netherlands, Heerlen, available at: https://opendata.cbs.nl/statline/\#/CBS/nl/dataset/70660ned/table?ts= 1515419163177

PAGE $42 \mid$ JOURNAL OF ENABLING TECHNOLOGIES $\mid$ VOL. 12 NO. 22018 
de Klerk, M.M.Y. (Ed.) (2005), Ouderen in instellingen (Older Adults in Institutions), The Netherlands Institute for Social Research, The Hague (in Dutch).

den Ouden, M., Kuk, N.O., Zwakhalen, S.M.G., Bleijlevens, M.H.C., Meijers, J.M.M. and Hamers, J.P.H. (2017), "The role of nursing staff in the activities of daily living of nursing home residents", Geriatric Nursing, Vol. 38 No. 3, pp. 225-30.

den Ouden, M., Bleijlevens, M.H.C., Meijers, J.M.M., Zwakhalen, S.M.G., Braun, S.M., Tan, F.E.S. and Hamers, J.P.H. (2015), "Daily (in)activities of nursing home residents in their wards: an observation study", Journal of the American Medical Directors Association, Vol. 16 No. 11, pp. 963-8.

Edvardsson, D., Petersson, L., Sjogren, K., Lindkvist, M. and Sandman, P.O. (2013), "Everyday activities for people with dementia in residential aged care: associations with person-centredness and quality of life", International Journal of Older People Nursing, Vol. 9 No. 4, pp. 269-76.

Fielding, R.A., Vellas, B., Evans, W.J., Bhasin, S., Morley, J.E., Newman, A.B., Abellan van Kan, G., Andrieu, S., Bauer, J., Breuille, D., Cederholm, T., Chandler, J., De Meynard, C., Donini, L., Harris, T., Kannt, A., Keime Guibert, F., Onder, G., Papanicolaou, D., Rolland, Y., Rooks, D., Sieber, C., Souhami, E., Verlaan, S. and Zamboni, M. (2011), "Sarcopenia: an undiagnosed condition in older adults. Current consensus definition: prevalence, etiology, and consequences. International working group on sarcopenia", Journal of the American Medical Directors Association, Vol. 12 No. 4, pp. 249-56.

lecovich, E. and Rabin, B. (2014), "Practices used in Israel by nurses who care during hospitalization who care during hospitalization or who are bedridden", American Journal of Alzheimer's Disease \& Other Dementias, Vol. 25 No. 2, pp. 167-78.

Imai, M., Kuwahara, Y., Hirai, M., Nishimura, R., Nishimura, N., Shimizu, Y., Fujii, T. and Iwase, S. (2015), "Effects of defecation strain at various bed reclining angles on intrarectal pressure and cardiovascular responses", Nursing Research, Vol. 64 No. 6, pp. 413-21.

Okuwa, M., Sanada, H., Sugama, J., Inagaki, M., Konya, C., Kitagawa, A. and Tabata, K. (2006), "A prospective cohort study of lower-extremity pressure ulcer risk among bedfast older adults", Advances in Skin and Wound Care, Vol. 19 No. 7, pp. 391-7.

Rubin, E.B., Buehler, A.E. and Halpern, S.D. (2016), "States worse than death among hospitalized patients with serious illnesses", JAMA Internal Medicine, Vol. 176 No. 10, pp. 1557-9.

Strating, N., van Herpen, R. and Zeiler, W. (2015), "Evacuatie van bedgebonden patiënten (Evacuation of bedbound patients)", TWL Magazine, Vol. 44 No. 2, pp. 46-8 (in Dutch).

Swanborn, P. (2013), Case studies. Wat, wanneer en hoe? (Case studies. What, when and how?), Boom Lemma, Amsterdam.

van Hoof, J., Wetzels, M.H., Dooremalen, A.M.C., Overdiep, R.A., Nieboer, M.E., Eyck, A.M.E., van Gorkom, P.J.L.M., Zwerts-Verhelst, E.L.M., Aarts, S., Vissers-Luijcks, C., van der Voort, C.S., Moonen, M.J.G.A., van de Vrande, H.A., van Dijck-Heinen, C.J.M.L. and Wouters, E.J.M. (2015), "Exploring innovative solutions for quality of life and care of bed-ridden nursing home residents through co-design sessions", Journal of Aging Research, Vol. 2015, 14pp., available at: http://dx.doi.org/10.1155/2015/185054

Zegelin, A. (2008), “'Tied down' - The process of becoming bedridden through gradual local confinement”, Journal of Clinical Nursing, Vol. 17 No. 17, pp. 2294-301.

\section{Author Affiliations}

I. Martens was based at the Fontys Centre for Healthcare and Technology, Fontys University of Applied Sciences, Eindhoven, The Netherlands; and is at the Academy for Healthcare, Avans University of Applied Sciences, Tillburg, The Netherlands.

H. Verbeek is based at the CAPHRI School for Public Health and Primary Care, Department of Health Services Research, Maastricht University, Maastricht, The Netherlands.

J. Aarts is based at the Wissner-Bosserhoff Nederland, Dordrecht, The Netherlands.

W.P.H. Bosems is based at the Fontys Centre for Healthcare and Technology, Fontys University of Applied Sciences, Eindhoven, The Netherlands and the Institute of Allied Health Professions, Fontys University of Applied Sciences, Eindhoven, The Netherlands. 
E. Felix was based at Vitalis WoonZorg Groep, Vitalis Brunswijck, Eindhoven, The Netherlands and at the Institute of Allied Health Professions, Fontys University of Applied Sciences, Eindhoven, The Netherlands.

J. van Hoof was based at the Fontys Centre for Healthcare and Technology, Fontys University of Applied Sciences, Eindhoven, The Netherlands; the Institute of Allied Health Professions, Fontys University of Applied Sciences, Eindhoven, The Netherlands; Faculty of Social Work and Education, The Hague University of Applied Sciences, The Hague, The Netherlands and Faculty of Environmental Engineering and Geodesy, Department of Spatial Economy, Wrocław University of Environmental and Life Sciences, Wroclaw, Poland.

\section{Corresponding author}

J. van Hoof can be contacted at: jvhoof1980@hotmail.com; j.vanhoof@hhs.nl

For instructions on how to order reprints of this article, please visit our website: www.emeraldgrouppublishing.com/licensing/reprints.htm

Or contact us for further details: permissions@emeraldinsight.com 